\title{
The effect of supplementing cows with live yeast, Saccharomyces cerevisiae, on ciliate fauna and ruminal fermentation
}

\author{
B. Kowalik ${ }^{1}$, T. Michałowski, J.J. Pająk, M. Taciak and J. Rawa \\ The Kielanowski Institute of Animal Physiology and Nutrition, Polish Academy of Sciences \\ 05-110 Jabłonna, Poland
}

(Received 24 August 2007; revised version 4 March 2008; accepted 8 April 2008)

\begin{abstract}
The influence of a live culture of Saccharomyces cerevisiae on the number of ciliates, activity of carboxymethylcellulose- (CMC), xylan- and starch-degrading enzymes, as well as the concentration of VFA in the rumen of two cows was examined. The animals were fed either hay and concentrate alone or supplemented with live yeast given at the rate of $5 \mathrm{~g} / \mathrm{d}$. It was found that the response of rumen fauna to yeast supplementation was related to the animal. The total protozoa and Entodinia counts increased significantly only in one cow $(\mathrm{P} \leq 0.05)$. The number of protozoa from the genus Diplodinium remained unchanged (cow 1) or decreased significantly (cow 2). Epidinia decreased in the rumen of both animals, while Isotrichidae did not change significantly ( $\mathrm{P}>0.05)$. The activity of CMC-ase and xylan-degrading enzymes varied between 7.2-9.4 and 108.3-130.0 $\mu \mathrm{M}$ released reducing sugars $/ \mathrm{g} \mathrm{DM} / \mathrm{h}$, respectively. The effect of yeast on the activity of fibrolytic enzymes was related to the host animal. CMC-ase decreased significantly only in cow 2, while xylanase, in cow 1. The activities of starch-degrading enzymes as well as $\mathrm{pH}$ of rumen fluid and volatile fatty acids were not affected by supplementation of cows with yeast.
\end{abstract}

KEY WORDS: rumen, protozoa, yeast, carboxymethylocellulase, xylanase, VFA

\section{INTRODUCTION}

Live yeast have been fed to ruminants for more than 70 years. Nonetheless, their effect on rumen microbiota, especially on protozoa inhabiting in this chamber, is still not well known. The response of rumen fauna and some of the morphological groups of rumen protozoa was studied by Doreau and Jouany, (1998), Jouany et al. (1998), Mwenya et al., (2005) and Galip (2006), but the results were inconsistent

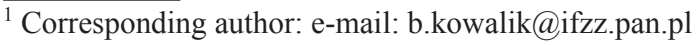


despite the nutritional and environmental requirements of the examined groups of rumen ciliates differing significantly (Williams and Coleman, 1992).

The effect of yeast on carbohydrate digestion and fermentation in the rumen also has not been well defined yet. It has been shown that the supplementation of feed with yeast increased the digestibility of NDF and ADF (Newbold et al., 1995). However, neither Kmet' et al. (1992) nor Brossard et al. (2006) were able to show a positive effect of live yeast on cellululoytic and amylolytic activity in the rumen content. In addition, Koul et al. (1998) and Doležal et al. (2005), observed an increase in the concentration of VFA and in the proportion of acetate. In contrast, Chaucheyras et al. (1996) and Brossard et al. (2006) showed that neither total VFA nor acetate and propionate were influenced by enrichment of the diet with yeast.

The objective of this study was to compare the response of ciliates inhabiting the rumen of two cows to the supplementation of the hosts with a live culture of $S$. cerevisiae. The effect of yeast on the activity of fibrolytic and amylolytic enzymes as well as on $\mathrm{pH}$ and concentration of volatile fatty acids in the rumen fluid of both animals was also examined.

\section{MATERIAL AND METHODS}

The experiment was carried out on two rumen-fistulated Black-and-White Lowland cows. The animals were fed a diet $(7.2 \mathrm{~kg} \mathrm{DM} / \mathrm{d})$ consisting of $87 \%$ meadow hay and $13 \%$ concentrate. The concentrate was composed of, $\%$ : crushed barley 80 , rapeseed oilmeal 10 , and soyabean oilmeal 10 . The supplemental dose of a vitamin-mineral mixture was $50 \mathrm{~g} / \mathrm{d}$. The daily ration was divided into two equal parts and fed at 8.00 and $16.00 \mathrm{~h}$. A dose of $5 \mathrm{~g}$ of live Saccharomyces cerevisiae CNCM I-1077 ( $\left.1 \cdot 10^{10} \mathrm{CFU} / \mathrm{g}\right)$, when given, was introduced into the rumen of animals at $8.00 \mathrm{~h}$ via the fistula. Drinking water was available ad libitum.

The period of preliminary feeding of cows lasted for four weeks and was followed by the sampling period. The samples of fluid and digesta were taken from the rumen just before the morning feeding and at 2, 4 and $8 \mathrm{~h}$ thereafter. The sampling was repeated on three consecutive days. The samples of rumen content for enzymatic examination $(20 \mathrm{~g})$ were frozen and kept at $-20^{\circ} \mathrm{C}$, whereas these for protozoa counts $(5 \mathrm{~g})$ were fixed with aqueous formaldehyde $(4 \% \mathrm{~W} / \mathrm{V})$. Samples of rumen fluid for determination of volatile fatty acids $(5 \mathrm{ml})$ were preserved with $0.5 \mathrm{ml}$ of formic acid. To obtain representative samples, the content and fluid were taken from different places in the rumen. The withdrawn material was thoroughly mixed and the appropriate samples were collected while the remaining material was immediately replaced in the rumen.

The samples of rumen content for enzymatic studies were treated with $\mathrm{CCl}_{4}$ according to Huhtanen and Khalili (1992) and the obtained preparation was used 
to determine the activity of carboxymethylcellulose- (CMC), xylan- and starchdegrading enzymes. The reaction mixture consisted of $750 \mu 1$ of $2 \%(\mathrm{~W} / \mathrm{V})$ substrate dissolved in McIlvaine buffer ( $\mathrm{pH}$ 6.0), $50 \mu$ of enzyme preparation and $450 \mathrm{ml}$ of the same buffer. It was incubated for $1 \mathrm{~h}$ at $40^{\circ} \mathrm{C}$ and the released reducing sugars were measured using the dinitrosalicilic acid reagent (Miller et al., 1960) and a Beckman DU-64 Spectrophotometer. The concentration of VFA in rumen fluid was determined by gas chromatography according to Ziołecki and Kwiatkowska (1973) using a Hewlett Packard 5890 apparatus. The $\mathrm{pH}$ of rumen fluid was measured using a Beckman $\mathrm{pH}$-meter. The protozoa were identified and classified according to Dogiel (1927) and counted under a light microscope according to Michałowski et al. (2001).

The statistical calculations were carried by the tests using the Statistica 5.1. software package. The normality of the distribution of variables was tested by the Shapiro-Wilk test. Mean values were calculated and compared by the pairedsamples Student-t test for normal distribution. Variables without normal distribution were elaborated by the Wilcoxon test.

\section{RESULTS}

\section{Rumen ciliates}

The ciliate fauna of the cows was composed of twenty one species belonging to four genera of the family Ophryoscolecidae as well as three species from the family Isotrichidae. The genus Entodinium was represented by Entodinium simplex Entodinium caudatum, Entodinium vorax, Entodinium bimastus, Entodinium rostratum, Entodnium longinucleatum, Entodinium exiguum, Entodinium nanellum, Entdinium dubardi and Entodinium minimum. The Diplodinium fauna was composed of Anoplodinum posterovesiculatum, Anoplodinium denticulatum, Eudiplodinium maggii, Eudiplodinium rostratum, Eudiplodinium medium, Polyplastron multivesiculatum, Ostracodinium gracilie and Ostracodinium obtusum dilobum. The genus Epidinium was represented by only Epidinium ecaudatum caudatum and family Isotrichidae, by Isotricha prostoma, Isotricha intestinalis and Dasytricha ruminantium.

The concentration of ciliates in the rumen of both cows is presented in Table 1. In cow No. 1, the total number of protozoa and Entodinium count were significantly higher when this animal was fed the experimental diet compared with the control. The concentration of ciliates from the remaining groups was not affected by the diet. The total concentration of protozoa as well as the number of Entodinium and Isotrichidae in cow No. 2 remained unchanged when yeast was added to the control diet composed of hay and concentrate. In contrast, the number of Diplodinium and Epidinium decreased significantly. 
Table 1 . The concentration of ciliates $\left(\times 10^{3} / \mathrm{g}\right.$ digesta $)$ in the rumen of cows fed hay and concentrate diet alone (control) or supplemented with live yeast (cxperimental)

\begin{tabular}{|c|c|c|c|c|c|c|}
\hline \multirow{2}{*}{ Item } & \multicolumn{3}{|c|}{ Cow 1} & \multicolumn{3}{|c|}{ Cow 2} \\
\hline & control & experimental & SEM & control & experimental & SEM \\
\hline Total protozoa & $419.3^{a}$ & $515.6^{\mathrm{b}}$ & 23.29 & 366.3 & 337.0 & 14.57 \\
\hline Entodinium & $370.3^{\mathrm{a}}$ & $468.8^{\mathrm{b}}$ & 23.32 & 290.9 & 290.5 & 13.62 \\
\hline Diplodinium & 27.4 & 24.8 & 0.10 & $32.8^{\mathrm{A}}$ & $20.7^{\mathrm{B}}$ & 1.99 \\
\hline Epidinium & 4.2 & 2.4 & 0.78 & $27.0^{\mathrm{A}}$ & $7.5^{\mathrm{B}}$ & 2.51 \\
\hline Isotrichidae & 17.3 & 19.5 & 2.05 & 15.6 & 18.3 & 1.62 \\
\hline
\end{tabular}

$\mathrm{A}, \mathrm{B}-\mathrm{P} \leq 0.01{ }^{\mathrm{ab}}-\mathrm{P} \leq 0.05$; SEM - standard error of mean

\section{Carbohydrate digestion}

The activity of enzymes involved in the digestion of structural carbohydrates and starch is presented in Table 2 . The activity of xylan degrading enzymes was higher when cow No. 1 was fed the control diet compared with the yeast-supplemented diet. The activity of CMC and starch degrading enzymes remained unchanged. The activity of CMC-ase in the rumen of cow No. 2 was significantly lower when this animal was fed the diet supplemented with yeast than when control feed was given. The xylan- and starch-degrading enzymes were not affected by the diet.

Table 2 . The activity of CMC-ase, xylan and starch degrading enzymes ( $\mu \mathrm{M}$ released reducing sug$\mathrm{ars} / \mathrm{g} \mathrm{DM} / \mathrm{min}$ ) in the rumen content of cows fed hay and concentrate alone (control) or diet supplemented with yeast (experimental)

\begin{tabular}{lccccccc}
\hline \multirow{2}{*}{ Substrates } & \multicolumn{3}{c}{ Cow 1} & & \multicolumn{3}{c}{ Cow 2 } \\
\cline { 2 - 4 } \cline { 7 - 8 } & control & experimental & SEM & & control & experimental & SEM \\
\hline CMC & 7.8 & 7.3 & 0.52 & & $9.4^{\mathrm{A}}$ & $7.2^{\mathrm{B}}$ & 0.45 \\
Xylan & $130.0^{\mathrm{A}}$ & $108.3^{\mathrm{B}}$ & 4.00 & & 126.2 & 124.3 & 4.49 \\
Starch & 23.0 & 23.9 & 0.81 & & 24.7 & 27.4 & 0.99 \\
\hline
\end{tabular}

$\mathrm{A}, \mathrm{B}$ - $\mathrm{P} \leq 0.01$; SEM - standard error of mean

\section{Fermentation products}

No significant differences were found between $\mathrm{pH}$ or between the concentration of total VFA and particular acids in the rumen fluid of cows fed control and experimental diets (Table 3 ). 
Table 3. Effect of live yeast on $\mathrm{pH}$ and concentration of total and particular acids in the rumen of cows (mmol/l) fed diet without (control) and with yeast supplement (experimental)

\begin{tabular}{lccccccc}
\hline \multirow{2}{*}{ Item } & \multicolumn{3}{c}{ Cow 1 } & & \multicolumn{3}{c}{ Cow 2 } \\
\cline { 2 - 4 } & control & experimental & SEM & & control & experimental & SEM \\
\hline pH & 7.1 & 7.1 & 0.03 & & 6.8 & 6.8 & 0.05 \\
Total VFA & 75.5 & 78.0 & 2.57 & & 98.6 & 98.1 & 3.63 \\
Acetate & 61.8 & 61.0 & 1.93 & & 79.9 & 77.0 & 3.04 \\
Propionate & 7.9 & 8.4 & 0.41 & & 11.1 & 10.9 & 0.48 \\
Butyrate & 4.8 & 4.6 & 0.20 & & 5.6 & 5.5 & 0.24 \\
Valerate & 0.5 & 0.4 & 0.02 & & 0.7 & 0.7 & 0.06 \\
Isovalerate & 0.5 & 0.6 & 0.02 & & 0.6 & 0.6 & 0.02 \\
Isobutyrate & 0.5 & 0.5 & 0.01 & & 0.5 & 0.5 & 0.01 \\
\hline
\end{tabular}

SEM - standard error of mean

\section{DISCUSSION}

Twenty-one species comprised the rumen ciliate fauna of cows. The population density of particular species was not determined because the identification of particular species after feeding the host animals was nearly impossible. This concerns especially the small Entodinia, as numerous individuals from this group were filled with starch granules and this precluded their true identification.

The response of rumen ciliates to the supplementation of cows with Saccharomyces cervisiae varied in relation to the host and group of microorganisms. The effect of this additive on the total number of protozoa found in our experiment was consistent with the relationships described earlier by Doreau and Jouany, (1998) and Mwenya et al. (2005) if their results are considered together, as the cited authors observed either a positive reaction or no effect. In contrast to the results obtained in our study and in the experiments cited above, Newbold et al. (1995) observed a negative effect of yeast NCYC 240, NCYC 694, and Yea-Sacc on the population density of rumen ciliates. These studies were, however, performed under in vitro conditions using a Rusitec system, which provides growth conditions differing considerably from those in the rumen. It is also noteworthy that changes in the total number of protozoa always reflect changes in the most numerous group of ciliates and Entodinia have most often been such a population (Williams and Coleman, 1992). This was also the case with the cows used in the reported studies.

Galip (2006) reported that the number of ciliates from the genus Diplodinium decreased when rams were fed a diet supplemented with yeast, while Doreau and Jouany (1998) did not observe changes in the number of Diploplastron affine, which often are an important representative of the genus Diplodinium. In general, our results are in accordance with the findings of the cited authors since Diplodi- 
nia either decreased (cow 2) or remained unchanged (cow 1) when live cultures of Saccharomyces cerevisiae were given to the animals. In contrast to Diplodinia, ciliates from the genus Epidinium reacted negatively to the supplementation of cows with yeast and such a response was observed in the case of both cows. Unfortunately, no relevant data were found in available literature and due to this no comparison was possible.

The ciliates from the family Isotrichidae were the only protozoa that did not change when live cultures of Saccacharomyces cerevisiae were supplemented to the rumen of cows. Thus, the findings obtained in our experiment are in accordance with the results of Doreau and Jouany (1998) and Galip (2006) who supplemented sheep with yeast. Such a result can suggest that these protozoa were either less sensitive than ophryoscolecids to the changes in the rumen ecosystem caused by the additives or that yeast did not influence the growth conditions required by the rumen holotrichs.

The supplementation of the diet with yeast lowered the activity of CMC-ase in cow No. 2 and xylan-degrading enzymes in cow No. 1. This suggests that live cultures of Saccacharomyces cerevisiae negatively influenced some of the microorganisms that are able to synthesize fibrolytic enzymes. According to Dehority (1993), the most cellulolytic species of rumen ciliates are Eudiplodinium maggii and Ostracodinium obtusum, which belong to the genus Diplodinium. Both of them were present in the rumen of cows. On the other hand, the ciliates Epidinium ecaudatum caudatum are also characterized by high fibrolytic activity (Takenaka et al., 1999, Michałowski et al., 2001, Wereszka et al., 2004). All of the protozoa and Anoplodinium denticulatum also exhibited the ability to digest xylan (Stan et al., 2006). The comparison of the obtained data suggest a relationship between the changes in the number fibrolytic ciliates and in fibrolytic activity. Unfortunately, the only relationship that was found here was the positive correlation between the number of Dilodiunium and the activity of the mentioned enzymes in the rumen of cow No. 2. No such relationship was found in relation to ciliates from the genus Epidinium. On the other hand, the concentration of these ciliates in the rumen of both cows was presumably too low to have a significant impact on the total activity of enzymes involved in the degradation of dietary polysaccharides

In contrast to the findings of Kmet' et al. (1992), yeast had no effect on the activity of enzymes involved in starch digestion in the rumen of cows. Such findings may suggest that either the impact of protozoa on the total activity of amylolytic enzymes was not very important or that the changes in this activity resulting from the changes in the ciliate count were compensated by appropriate changes in amylolytic bacteria. This last suggestion is supported by the negative correlation between ciliates and amylolytic bacteria in the rumen (Ushida et al., 1991).

The results of the measurements of $\mathrm{pH}$ and quantification of VFA showed that supplementation of cows with yeast did not change the fermentation pattern in 
the rumen of these animals. Thus they are consistent with the data of the in vitro and in vivo studies of Newbold et al. (1995) and Marrero et al. (2006), respectively, but contradictory to the findings of Strzetelski et al. (1995) and Doležal and Doležal (2005), who reported that the addition of live $S$. cerevisiae to the diet increased the concentration of VFA in the rumen fluid of ruminants. They are also inconsistent with the results of Zeleňák et al. (1994), Lynch and Martin (2002) and Mwenya et al. (2005) who reported that not only the total concentration, but also the molar proportion of particular acids were influenced by yeast supplementation. The fermentation pattern in the rumen of cows was characterized by a very high proportion of acetate, which contributed up to $80 \%$ of total VFA. This may suggest that the microorganisms involved in acetate production predominated in the rumen of the examined animals. On the other hand, the absence of changes in VFA concentration and in molar proportions of particular acids suggest that yeast given to cows did not influence the population of the microorganisms mentioned above. Further inspection of the results also suggests that the impact of protozoa on carbohydrate metabolism was rather small because the concentration of butyrate was much lower than propionate, and such a proportion is not typical of these organisms (Michałowski, 1987).

\section{CONCLUSIONS}

The non-uniform reaction of ciliates to supplementation of the host with yeast resulted presumably from differences in the sensitivity of particular groups of protozoa to the changes in the rumen environment caused by the additive. On the other hand, the non-uniform response of similar groups of ciliates inhabiting in the rumen of two different hosts resulted presumably from differences in the reaction of the compared rumen ecosystems to the same doses of yeast. Despite the drop in the activity of enzymes involved in fibre degradation, neither the quantity of carbohydrates fermented in the rumen nor the microorganisms responsible for the fermentation pattern were probably significantly influenced by yeast in the offered dose.

\section{REFERENCES}

Brossard L., Chaucheyras-Durand F., Doreau B.M., Martin C., 2006. Dose effect of live yeasts on rumen microbial communities and fermentations during butyric latent acidosis in sheep: new type interaction. Anim Sci. 82, 829-836

Chaucheyras F., Fonty G., Bertin G., Salmon J.M., Gouet P., 1996. Effect of strain of Saccharomyces cerevisiae (levucell $\mathrm{SC} 1$ ), a microbial additive for ruminants, on lactate metabolism in vitro. Can. J. Microbiol. 42, 927-933 
Dehority B.A., 1993. Microbial ecology of cell wall fermentation. In: H.G. Jung, D.R. Buxton, R.D. Hatfield, J. Ralph (Editors). Forage Cell Wall Structure and Digestibility. ASA-CSSA-SSSA, Madison, WI (USA), pp. 425-453

Dogiel V.A., 1927. Monographie der Familie Ophryoscolecidae. Arch. Protistenkd. 59, 1-288

Doležal P., Doležal J., 2005. The yeast culture Saccharomyces cerevisiae (Strain 47) as manipulator of rumen fermentation in postportal period of dairy cows. Nutr. Abstr. Rev., Ser. B 75 (10), Abstr. 4733

Doležal P., Doleźal J., Trinačty J., 2005. The yeast culture Saccharomyces cerevisiae on ruminal fermentation in dairy cows. Czech J. Anim. Sci. 50, 503-510

Doreau M., Jouany J.P., 1998. Effect of a Saccharomyces cerevisiae culture on nutrient digestion in lactating dairy cows. J. Dairy Sci. 81, 3214-3221

Galip N., 2006. Effect of supplemental yeast culture and sodium bicarbonate on ruminal fermentation and blood variables in rams. J. Anim. Physiol. Anim. Nutr. 90, 446-452

Huhtanen P.P., Khalili H., 1992. The effect of sucrose supplement on the particle-associated carboxymethylcellulase (EC 3.2.1.4) and xylanase (EC 3.2.1.8) activities in cattle given grass-sillage-based diet. Brit. J. Nutr. 67, 245-255

Jouany J.P., Mathieu F., Senaud J., Bohatier J., Bertin G., Mercier M., 1998. The effect of Saccharomyces cerevisiae and Aspergillus oryzae on the digestion of the cell wall fraction of a mixed diet in defaunated and refaunated sheep rumen. Reprod. Nutr. Develop. 38, 401-416

Kmet V., Jonecova Z., Stachova M., 1992. The effect of pectinolytic yeast on rumen microflora. J. Anim. Feed Sci. 1, 165-170

Koul V., Kumar U., Sareen V.K., Singh S., 1998. Mode of action of yeast culture (Yea-Sacc 1026) for stimulation of rumen fermentation in buffalo calves. J. Sci. Food Agr. 77, 407-413

Lynch H.A., Martin S.A., 2002. Effect of Saccharomyces cerevisiae culture and Saccharomyces cerevisiae live cell on in vitro mixed ruminal microorganism fermentation. J. Dairy Sci. 85, 2603-2608

Marrero Y., Galindo J., Elias A., Moreira O., Cueto M., 2006. Effect of biological preparations with viable yeasts on the microbial population in rumen and fermentative indicators in cows fed fibrous diets. Cuban J. Agr. Sci. 3, 321-329

Michałowski T., 1987. The volatile fatty acid production by ciliate protozoa in the rumen of sheep. Acta Protozool. 26, 335-345.

Michałowski T., Rybicka K., Wereszka K., Kasperowicz A., 2001. Ability of the rumen ciliate Epidinium ecaudatum to digest and use crystaline cellulose and xylan for in vitro growth. Acta Protozool. 40, 203-210

Miller G.L., Blum R., Glennon W.E., Butron A.L., 1960. Measurement of carboxymethylcellulase activity. Anal. Biochem. 2, 127-132

Mwenya B., Santoso B., Sar C., Pen B., Morikawa R., Takaura K., Umetsu K., Kimur K., Takhashi J., 2005. Effect of yeast culture and galacto-oligosaccharides on ruminal fermentation in Holstein cows. J. Dairy Sci. 88, 1404-1412

Newbold C.J., Wallace R.J., Chen X.B., McIntosh F.M., 1995. Different strains of Saccharomyces cerevisiae differ in their effect on ruminal bacterial numbers in vitro and in sheep. J. Anim. Sci. 73, 1811-1818

Stan K., Bełżecki G., Kasperowicz A., Kwiatkowska E., Michałowski T., 2006. The ability of the rumen ciliates Anoplodinium denticulatum to utilize hemicellulosic material for in vitro growth. J. Anim. Feed Sci. 15, Suppl.1, 39-42

Strzetelski J.A., Maciejewicz-Ryś J., Ryś R., Kowalczyk J., Niwińska B., Stasiniewicz T., Maciaszek K., 1995. Yeast cell as a feed suplement for cattle. 2. Effect of liquid yeast cultures on digestive processes in the rumen of bulls. J. Anim. Feed Sci. 4, 287-297 
Takenaka A., D’Silva C.G., Kudo H., Itabashi H., Cheng K.J., 1999. Molecular cloning, expression, and characterization of an endo- $\beta-1,4$-glucanase cDNA from Epidinium caudatum. J. Gen. Appl. Microbiol. 45, 57-61

Ushida K., Jouany J.-P., Demeyer D.I., 1991. Effects of presence or absence of rumen protozoa on the efficiency of utilization of concentrate and fibrous feeds. In: T. Tsuda, Y. Sasaki, R. Kawashima (Editors). Physiological Aspects of Digestion and Metabolism in Ruminants. Proceedings of the Seventh International Symposium on Ruminant Physiology. Academic Press, New York, pp. 625-654

Wereszka K., McIntosh F. M., Michałowski T., Jouany J.P., Nsabimana E., Macheboeuf D., McEwan N. R., Newbold C. J., 2004. A cellulase produced by the rumen protozoan Epidinium ecaudatum is of bacterial origin and has an unusual pH optimum. Endocyt. Cell Res. 15, 561-569

Williams A.G., Coleman G.S., 1992. The Rumen Protozoa. Springer-Verlag, New York

Zeleňák I., Jalč D., Kmet' V., Siroka P., 1994. Imfluence of diet and yeast supplemented on in vitro ruminal characteristics. Anim. Feed Sci. Tech. 49, 211-221

Ziołecki A., Kwiatkowska E., 1973. Gas chromatography of $\mathrm{C}_{1}$ to $\mathrm{C}_{5}$ fatty acids in rumen fluid and fermentation media. J. Chromatogr. 80, 250-254 